\title{
Research on the Working Status of Party Member Supervisor Function from the Perspective of Whole Staff Education
}

\author{
Kehan Zhang \\ Shanghai University of Engineering Science, Shanghai, 201620, China
}

Keywords: Party member supervisor, Whole staff education, Investigation report.

\begin{abstract}
Adhering to taking the education as the priority is the radical task of higher education. Every teacher in colleges and universities is education worker. Among them, the party member teachers should play a leading role and take educational responsibilities consciously and actively, fully exploiting the education function of teaching, scientific research, management and other various jobs. This paper takes teachers and students of eight colleges which took part in Shanghai "the backbone teacher's teaching incentive plan" as the research objects to understand the working status and functions in education which the teachers especially party member teachers have in the process of teaching and provides reference in exploring the mechanism in which the party member supervisor to participate in the whole staff education.
\end{abstract}

\section{The rise of the problem}

The report of the18th National Congress of the Communist Party of China puts forward that "moral education should be the fundamental task of education and socialist builders with the comprehensive development in morality, intelligence, physics and aesthetics should be cultivated." "The decision of Central Committee of the Communist Party of China on comprehensively deepening reform and other certain major issues" proposed to "deepen comprehensive reform in education field", which clarifies about the new requirement for the development of higher education reform under the new situation of the new requirements. Comrade Liu Yandong points out that the morality construction should be throughout the whole comprehensive reform process. Facing new opportunities, talent training must be firmly established in the centre of the reform of higher education, insisting on the principles of party spirit, adhering to the education, with moral education as the priority, and further promote the whole staff education, the whole process education and comprehensive education.

In this round of reform of higher education, Shanghai Municipal Education Commission launched the "backbone head would incentive plan", and tried it in eight colleges and universities as Shanghai University of Engineering Science, Shanghai University, Institute of Medicine of Shanghai Jiaotong University, Shanghai University of Traditional Chinese Medicine, Shanghai Normal University, Shanghai Maritime University, Shanghai Ocean University, Shanghai Second Industrial University. According to the planning of reform, implementing "backbone head would incentive plan" is a reform in which teachers are encouraged to teach in the through real movement to solve the problems and focus on giving priority to students, and improve the students' practical ability. In this plan, professor, associate professor must take the undergraduate course, and professors, associate professors should be encouraged to guide students' social practice, graduation design and graduation thesis, namely teach as a supervisor. In the process of guiding students at the same time supervisors especially party member supervisors should strengthen ideological guidance to consciously take the educational function, effectively play a role of educating and bring new enlightenment for the educational work in colleges and universities.

\section{The research situation and results}

This research takes the questionnaire form. As for the choice of research object, Shanghai University of Engineering and Technology and other 7 colleges which participated in Shanghai "backbone head would incentive plan" are selected. Questionnaire is divided into two kinds, 
respectively takes teachers and students as the research objects to understand the status quo, difficulties and problems for teachers in teaching students. The investigation sent out 490 teacher questionnaires, and recovered 476, and the recovery rate is $97.1 \%$; distributed 920 student questionnaires with 904 recollected, and the recovery rate is $98.3 \%$. There are 19 topics on teacher questionnaire, 18 of them are closed or semi-closed topics. 1 is open topic, and the content involves the basic situation of teaching, instruction content and guiding method, guide will as three aspects; Student questionnaire has 17 items, including 15 closed or semi-closed subjects, 2 open topics, and the content involves the teaching basic situation, mentor to guide contents and the way of guidance, guidance effect as three aspects.

Table 1. Statistic of investigation sample distribution

\begin{tabular}{|c|c|c|c|c|c|c|}
\hline category & variable & \multicolumn{5}{|c|}{ variable definition } \\
\hline \multirow{8}{*}{$\begin{array}{c}\text { Teacher } \\
\text { Questionnaire }\end{array}$} & \multirow{2}{*}{ Politic status } & $\begin{array}{c}\text { Member of } \\
\text { CPC }\end{array}$ & $\begin{array}{c}\text { Democratic } \\
\text { parties }\end{array}$ & $\begin{array}{l}\text { General } \\
\text { public }\end{array}$ & & \\
\hline & & $87.4 \%$ & $4.6 \%$ & $8.0 \%$ & & \\
\hline & \multirow{2}{*}{$\begin{array}{l}\text { professional and } \\
\text { technical posts }\end{array}$} & Prof. & Vice Prof. & lecturer & Assistant & None \\
\hline & & $9.0 \%$ & $34.0 \%$ & $50.4 \%$ & $3.4 \%$ & $3.2 \%$ \\
\hline & \multirow{2}{*}{ Teaching age } & 1-2years & 3-5years & 6-10years & 11-20years & More than 20 \\
\hline & & $17.0 \%$ & $14.1 \%$ & $32.1 \%$ & $26.1 \%$ & $10.7 \%$ \\
\hline & \multirow[t]{2}{*}{ Position nature } & Teaching & Research & Managing & $\begin{array}{c}\text { Double } \\
\text { role }\end{array}$ & \\
\hline & & $63.0 \%$ & $16.8 \%$ & $11.8 \%$ & $8.4 \%$ & \\
\hline \multirow{5}{*}{$\begin{array}{c}\text { Student } \\
\text { Questionnaire }\end{array}$} & \multirow[t]{2}{*}{ Politic status } & $\begin{array}{l}\text { Member of } \\
\text { CPC }\end{array}$ & $\begin{array}{l}\text { League } \\
\text { Member }\end{array}$ & $\begin{array}{l}\text { General } \\
\text { public }\end{array}$ & & \\
\hline & & $11.8 \%$ & $83.7 \%$ & $4.5 \%$ & & \\
\hline & \multirow{3}{*}{ Grade } & Freshman & Sophomore & Junior & Senior & Fifth year(Medical \\
\hline & & & & & & Major) \\
\hline & & $48.7 \%$ & $17.0 \%$ & $23.3 \%$ & $9.3 \%$ & $1.7 \%$ \\
\hline
\end{tabular}

The working foundation for party member supervisor to participate in the education. Survey data show that in the teachers who have been surveyed, $75.4 \%$ of the teachers joined the "backbone teachers teaching incentive plan". According to the requirements of the project, teachers involved formed the project team in the way of projects with some college students. This shows that the teachers above have participated in the guidance and training to the students as mentors. According to the statistics of teachers, about $51.3 \%$ of the teachers supervise less than 10 students, and carry out educational work in small-scaled teaching team. This is good for education.

Table 2. The basic situation of the supervisor teaching

\begin{tabular}{|c|c|c|c|c|c|c|}
\hline Category & Investigation Contents & & & Opt & & \\
\hline \multirow{4}{*}{$\begin{array}{c}\text { Teacher } \\
\text { Questionnaire }\end{array}$} & \multirow{2}{*}{$\begin{array}{l}\text { Whether joined the "backbone teachers } \\
\text { teaching incentive plan" }\end{array}$} & Yes & No & $\begin{array}{c}\text { Going } \\
\text { to }\end{array}$ & $\begin{array}{l}\text { Not clear } \\
\text { about this }\end{array}$ & \\
\hline & & $75.4 \%$ & $16.8 \%$ & $3.8 \%$ & $4.0 \%$ & \\
\hline & \multirow{2}{*}{ Number of college students supervised } & $1-2$ & $3-5$ & $6-9$ & 10 and more & none \\
\hline & & $8.6 \%$ & $18.3 \%$ & $24.4 \%$ & $35.9 \%$ & $12.8 \%$ \\
\hline \multirow{2}{*}{$\begin{array}{c}\text { Student } \\
\text { Questionnaire }\end{array}$} & \multirow{2}{*}{ Whether the supervisors are party members } & Yes & No & $\begin{array}{l}\text { Not } \\
\text { clear }\end{array}$ & & \\
\hline & & $38.7 \%$ & $4.0 \%$ & $57.3 \%$ & & \\
\hline
\end{tabular}

In addition, from the comparative analysis of the data we have found that among the teachers participate in the "backbone head would incentive plan", party member teachers accounted for 72.6\%, and it is higher than the proportion published by party committee of Shanghai Municipal Education 
Commission in 2014 that "about half of teachers in colleges and universities are party member teachers". It shows that among the teachers join the "backbone head would incentive plan" and teach as a supervisor, the ratio of party member supervisor is higher, which lays the foundation for the party member supervisors to participate in the educational work.

The educational methods are flexible for party member supervisor. The statistics of the questionnaire of the party member supervisor shows that the teaching methods of supervisors are diversified and flexible. Through methods with which supervisors appointed with single or groups of students regularly or irregularly, they keep frequent contact with students. $49.2 \%$ of the teachers meet once a week with the students, and $51.3 \%$ of teachers communicate with students for about 1 hour at a time. And as for the way of communication, as much as $90.1 \%$ of supervisors choose counseling by face to face, in addition, E-mail, phone, WeChat, QQ and Fetion are used by the teachers to communicate with students.

Table 3. Statistics on the ways of teaching method

\begin{tabular}{|c|c|c|c|c|c|c|}
\hline Category & Investigation Contents & & & Options & & \\
\hline \multirow{8}{*}{$\begin{array}{c}\text { Teacher } \\
\text { Questionnaire }\end{array}$} & \multirow[t]{2}{*}{$\begin{array}{l}\text { Ways for guiding the student } \\
\text { (Multi-optional) }\end{array}$} & $\begin{array}{c}\text { Group } \\
\text { appointment }\end{array}$ & $\begin{array}{l}\text { Waiting } \\
\text { for } \\
\text { students }\end{array}$ & $\begin{array}{c}\text { Single } \\
\text { appointment } \\
\text { irregularly }\end{array}$ & $\begin{array}{c}\text { Group } \\
\text { appointment } \\
\text { irregularly }\end{array}$ & Other \\
\hline & & $48.1 \%$ & $15.5 \%$ & $55.5 \%$ & $25.2 \%$ & $5.3 \%$ \\
\hline & \multirow[t]{2}{*}{$\begin{array}{l}\text { Frequency of the appointment } \\
\text { with the students }\end{array}$} & Once a week & $\begin{array}{l}\text { Once } \\
\text { half a } \\
\text { month }\end{array}$ & $\begin{array}{l}\text { Once a } \\
\text { month }\end{array}$ & $\begin{array}{l}\text { Once a } \\
\text { semester }\end{array}$ & \\
\hline & & $49.2 \%$ & $29.2 \%$ & $15.8 \%$ & $5.8 \%$ & \\
\hline & \multirow[t]{2}{*}{$\begin{array}{l}\text { Average time for } \\
\text { communication }\end{array}$} & $\begin{array}{l}\text { Within } 30 \\
\text { mins }\end{array}$ & $\begin{array}{c}\text { 30mins } \\
\text { to1 } \\
\text { Hour }\end{array}$ & $\begin{array}{l}\text { 1hour to } \\
\text { 2hours }\end{array}$ & $\begin{array}{l}2 \text { hours and } \\
\text { above }\end{array}$ & \\
\hline & & $13.0 \%$ & $51.3 \%$ & $23.7 \%$ & $12.0 \%$ & \\
\hline & \multirow[t]{2}{*}{$\begin{array}{c}\text { Methods for } \\
\text { communication(Multi-optional) }\end{array}$} & Face to face & Email & Telephone & Wechat & $\begin{array}{l}\text { QQ or } \\
\text { Fetion }\end{array}$ \\
\hline & & $90.1 \%$ & $44.7 \%$ & $44.1 \%$ & $35.3 \%$ & $29.0 \%$ \\
\hline
\end{tabular}

The organic combination of professional education and ideological education by party member supervisor. According to the survey, in educational practice, party member supervisor channels ideological education thoughts into professional guidance.74.8\% of surveyed teachers think that it is necessary to guide the student ideologically and politically in the process of teaching and take it as their own responsibility. In the analysis of the samples of party member teacher questionnaire also found that about $52.0 \%$ of the party member supervisors get involved in the activities including guiding students to write applications, making students join the party contacts, making students' party membership, participating in the party defense or investigation, writing the party identification for the students, etc. And the survey on students shows that $25.1 \%$ of the students would communicate with supervisors with current affairs and thoughts despite professional communication. $22.9 \%$ of the students had discussed with the supervisors to join the party. 
Table 4. The status of the ideological teaching in education

\begin{tabular}{|c|c|c|c|c|c|c|}
\hline Category & $\begin{array}{c}\text { Investigation } \\
\text { Contents }\end{array}$ & & & Options & & \\
\hline \multirow{4}{*}{$\begin{array}{c}\text { Teacher } \\
\text { Questionnaire }\end{array}$} & \multirow[t]{2}{*}{$\begin{array}{l}\text { Is it necessary to } \\
\text { carry out ideological } \\
\text { education in } \\
\text { teaching? }\end{array}$} & $\begin{array}{c}\text { Yes, it’s } \\
\text { teacher's } \\
\text { responsibility }\end{array}$ & $\begin{array}{l}\text { No. That's the } \\
\text { responsibility } \\
\text { of counselor } \\
\text { and secretary }\end{array}$ & Other & & \\
\hline & & $74.8 \%$ & $21.0 \%$ & $4.2 \%$ & & \\
\hline & \multirow[t]{2}{*}{$\begin{array}{c}\text { Have you } \\
\text { participated in the } \\
\text { cultivation for } \\
\text { students to join the } \\
\text { party? }\end{array}$} & $\begin{array}{l}\text { Write } \\
\text { application } \\
\text { for students }\end{array}$ & $\begin{array}{l}\text { As the } \\
\text { contactor }\end{array}$ & $\begin{array}{l}\text { As the } \\
\text { introducer }\end{array}$ & $\begin{array}{l}\text { Participate } \\
\text { in the } \\
\text { defense }\end{array}$ & $\begin{array}{c}\text { Write } \\
\text { evaluation } \\
\text { for party } \\
\text { membership }\end{array}$ \\
\hline & & $21.6 \%$ & $15.3 \%$ & $11.8 \%$ & $11.6 \%$ & $16.8 \%$ \\
\hline \multirow{4}{*}{$\begin{array}{c}\text { Student } \\
\text { Questionnaire }\end{array}$} & \multirow[t]{2}{*}{$\begin{array}{l}\text { In what aspects the } \\
\text { supervisor has } \\
\text { communication with } \\
\text { you?(Multi-option) }\end{array}$} & $\begin{array}{l}\text { Professional } \\
\text { consultation }\end{array}$ & $\begin{array}{l}\text { Scientific } \\
\text { research }\end{array}$ & $\begin{array}{l}\text { discuss on } \\
\text { current } \\
\text { affairs and } \\
\text { ideology } \\
\end{array}$ & Daily life & other \\
\hline & & $54.2 \%$ & $34.8 \%$ & $25.1 \%$ & $32.9 \%$ & $5.3 \%$ \\
\hline & \multirow{2}{*}{$\begin{array}{c}\text { Does your supervisor } \\
\text { ask about your party } \\
\text { membership? }\end{array}$} & Yes & No & & & \\
\hline & & $22.9 \%$ & $77.1 \%$ & & & \\
\hline
\end{tabular}

The connotation of party member supervisor education meets the requirements of the teachers and students together. As for the surveyed teachers' understanding of teacher guidance contents, in addition to teaching for the students, according to the survey data from high to low arrangement, teachers choose answering questions and helping students to participate in scientific research innovation projects, guiding curriculum design or graduation thesis, guiding career and life planning, guiding students in political ideology and values and guiding students to participate in social practices. In the survey of students we found that content required by students is very close to the teachers'. In order they are guiding curriculum design or graduation thesis, guiding to participate in scientific research and innovation projects, helping in career and life planning, guiding social practice, solving ideological confusion, tutorial and answering questions. The requirements of teachers and students on guide content are similar, which explains that resonate happens in learning educational needs and feelings of both sides.

Table 5. The statistics of the teaching contents

\begin{tabular}{|c|c|c|c|c|c|c|c|c|}
\hline Category & Investigation Contents & & & & options & & & \\
\hline \multirow[t]{2}{*}{$\begin{array}{c}\text { Teacher } \\
\text { Questionnaire }\end{array}$} & \multirow[t]{2}{*}{$\begin{array}{l}\text { What contents should } \\
\text { be } \\
\text { taught(Multi-optional) }\end{array}$} & $\begin{array}{l}\text { Teaching } \\
\text { courses }\end{array}$ & $\begin{array}{c}\text { Solving } \\
\text { problems } \\
\text { and } \\
\text { consultation }\end{array}$ & $\begin{array}{l}\text { Consulting } \\
\text { students to } \\
\text { participate } \\
\text { in } \\
\text { innovation } \\
\text { projects }\end{array}$ & $\begin{array}{l}\text { Course } \\
\text { design or } \\
\text { paper } \\
\text { design }\end{array}$ & $\begin{array}{c}\text { Instructing } \\
\text { students to } \\
\text { participate } \\
\text { in social } \\
\text { practices }\end{array}$ & $\begin{array}{l}\text { Guild } \\
\text { student's } \\
\text { value } \\
\text { systems } \\
\text { and } \\
\text { ideology }\end{array}$ & $\begin{array}{l}\text { Guild } \\
\text { with } \\
\text { career } \\
\text { planning }\end{array}$ \\
\hline & & $68.7 \%$ & $82.1 \%$ & $80.5 \%$ & $70.0 \%$ & $54.2 \%$ & $55.0 \%$ & $56.7 \%$ \\
\hline \multirow[t]{2}{*}{$\begin{array}{c}\text { Student } \\
\text { Questionnaire }\end{array}$} & \multirow[t]{2}{*}{$\begin{array}{l}\text { What contents do you } \\
\text { want your supervisor } \\
\text { to guild } \\
\text { you?(Multi-optional) }\end{array}$} & $\begin{array}{l}\text { Individual } \\
\text { tutorship }\end{array}$ & $\begin{array}{l}\text { Guidance } \\
\text { with } \\
\text { researched }\end{array}$ & $\begin{array}{l}\text { Guidance } \\
\text { with } \\
\text { course } \\
\text { design and } \\
\text { paper } \\
\text { design }\end{array}$ & $\begin{array}{l}\text { Guidance } \\
\text { with } \\
\text { social } \\
\text { practice }\end{array}$ & $\begin{array}{l}\text { Guidance } \\
\text { with } \\
\text { ideology }\end{array}$ & $\begin{array}{l}\text { Guidance } \\
\text { with } \\
\text { career } \\
\text { planning }\end{array}$ & \\
\hline & & $40.2 \%$ & $61.5 \%$ & $61.8 \%$ & $42.9 \%$ & $40.9 \%$ & $54.9 \%$ & \\
\hline
\end{tabular}




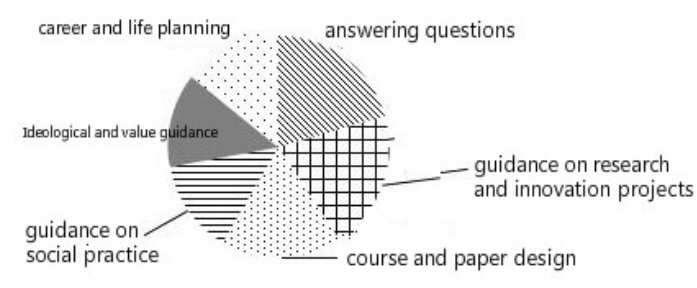

a. The expectations from students to the connotation of education

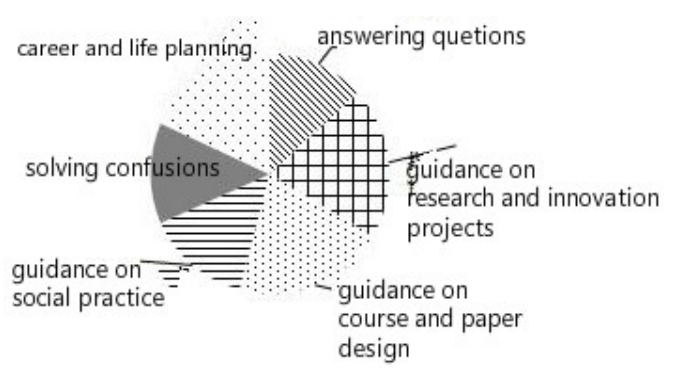

b. The expectations from teachers to the connotation of education

Fig. 1. The requirement of teachers and students on education contents are unified

Party member supervisor plays a significant role in the process of education. In the survey we found that $54.4 \%$ of the surveyed students think that teachers have influence on their studies and thoughts, and $74.7 \%$ of the students hope to continue this kind of learning, and $40.2 \%$ of the surveyed students think the supervisor has the most profound influence on their growth and development. The strong approval of students to teacher is the positive attitude towards the supervisors. Although teaching work adds the teachers' workload, $62.6 \%$ of the respondents think the supervising work brought educational achievement, and they are willing to continue to teach, and $22.9 \%$ of teachers think the supervising work can be organically combined with teaching scientific research, and they don't feel burdened obviously. It shows that teacher education is sustainable.

Table 6. Statistics on the influence of the supervisors

\begin{tabular}{|c|c|c|c|c|c|}
\hline Category & $\begin{array}{c}\text { Investigation } \\
\text { Contents }\end{array}$ & & optior & & \\
\hline \multirow[t]{2}{*}{$\begin{array}{c}\text { Teacher } \\
\text { Questionnaire }\end{array}$} & \multirow[t]{2}{*}{$\begin{array}{c}\text { Whether } \\
\text { teaching add } \\
\text { additional tasks } \\
\text { to your job }\end{array}$} & $\begin{array}{l}\text { It adds the working } \\
\text { task but also brings } \\
\text { the sense of } \\
\text { achievement, I'd like } \\
\text { to continue }\end{array}$ & $\begin{array}{l}\text { It can be } \\
\text { combined with my } \\
\text { own research on } \\
\text { education, there's } \\
\text { no obvious burden }\end{array}$ & $\begin{array}{l}\text { It adds many } \\
\text { tasks and I } \\
\text { don't have } \\
\text { high initiative }\end{array}$ & $\begin{array}{l}\text { It has contradiction } \\
\text { against my research } \\
\text { and management } \\
\text { work, I don't want to } \\
\text { teach }\end{array}$ \\
\hline & & $62.6 \%$ & $22.9 \%$ & $9.7 \%$ & $4.8 \%$ \\
\hline \multirow{6}{*}{$\begin{array}{c}\text { Student } \\
\text { Questionnaire }\end{array}$} & \multirow{2}{*}{$\begin{array}{l}\text { Whether the } \\
\text { supervisor gives } \\
\text { you positive } \\
\text { influence }\end{array}$} & $\begin{array}{l}\text { Both on study and } \\
\text { ideology }\end{array}$ & $\begin{array}{l}\text { On study, but less } \\
\text { on ideology }\end{array}$ & No influence & \\
\hline & & $54.4 \%$ & $24.9 \%$ & $20.7 \%$ & \\
\hline & \multirow{2}{*}{$\begin{array}{l}\text { Are you willing } \\
\text { to continue this } \\
\text { relationship }\end{array}$} & Yes & indifferent & No & \\
\hline & & $74.7 \%$ & $22.0 \%$ & $3.3 \%$ & \\
\hline & \multirow{2}{*}{$\begin{array}{c}\text { Who has the } \\
\text { deepest influence } \\
\text { on your growth }\end{array}$} & supervisor & teacher & counselor & other \\
\hline & & $40.2 \%$ & $29.1 \%$ & $25.3 \%$ & $5.4 \%$ \\
\hline
\end{tabular}

\section{Meditation and suggestion}

Party member supervisor should be the important part of the whole staff education work in colleges. Education is the first priority of higher education and every teacher in the college is educator. Education is not only about the imparting of knowledge and skills, but also includes the ideological and moral cultivation, promotion of physical strength and intelligence, etc. In the practice of the college education, subject teaching is the most economical, the most basic way and the natural platform for the party spirit education of college students. The charms of the personality, knowledge level, education attitude of party member supervisor will have unconscious influence on students. Fully exert the educational potential of this team of party member supervisor and introduce the thoughts of party member supervisor into the whole process of talent cultivation and make party 
member supervisor take the political responsibility of talent cultivation. Talents with qualified political qualities and enhance the whole staff education effectiveness.

Establish a scientific mechanism to guarantee party member supervisor to play a role in education. In the research, the surveyed teachers and students hold a positive attitude towards the party member supervisor in teaching but part of the surveyed teachers have doubts or concerns such as sustainability in the party member supervisor's positioning. Therefore, to ensure education effect, we shall establish a scientific mechanism to make sure the party member supervisor cultivation in full play, such as establishing a scientific system of teacher selection, and put forward requirements on the structure and formation of party member supervisor, enrich the education team; and as manage the education of party member supervisor by project operating, establishing clear educational target with process supervision to ensure the quality of education; and set up regular exchange platform for party member supervisors. The teachers and students can interact to communicate and share educational experiences and arouse the enthusiasm of teachers.

\section{Acknowledgments}

This paper is the item of "Sunshine Project" of Shanghai Municipal Education Commission and Shanghai Education Development Foundation. The item name: Study on the college party member education pattern based on the party member supervisor system. Item no. 13YG29

\section{References}

[1] Zhu Renbao. Meditation upon party construction and scientific education of teachers in colleges and universities,2013,(2):97-99

[2] Liu Yandong stresses:Comprehensively deepen higher education reform [OL]. [2014-7-21]. http://www.gov.cn/guowuyuan/2014-07/21/content_2721378.htm

[3] Municipal Education Commission puts forward "the backbone teacher's teaching incentive plan" returning to the nature of education [OL]. [2014-9-3]. http://sh.eastday.com/m/20140903/u1a8319879.html 